\title{
Impact of climate change on freshwater ecosystems: a global-scale analysis of ecologically relevant river flow alterations
}

\author{
P. Döll and J. Zhang \\ Institute of Physical Geography, Goethe University Frankfurt, Frankfurt am Main, Germany \\ Received: 8 February 2010 - Published in Hydrol. Earth Syst. Sci. Discuss.: 15 February 2010 \\ Revised: 4 May 2010 - Accepted: 10 May 2010 - Published: 21 May 2010
}

\begin{abstract}
River flow regimes, including long-term average flows, seasonality, low flows, high flows and other types of flow variability, play an important role for freshwater ecosystems. Thus, climate change affects freshwater ecosystems not only by increased temperatures but also by altered river flow regimes. However, with one exception, transferable quantitative relations between flow alterations and ecological responses have not yet been derived. While discharge decreases are generally considered to be detrimental for ecosystems, the effect of future discharge increases is unclear. As a first step towards a global-scale analysis of climate change impacts on freshwater ecosystems, we quantified the impact of climate change on five ecologically relevant river flow indicators, using the global water model WaterGAP 2.1g to simulate monthly time series of river discharge with a spatial resolution of 0.5 degrees. Four climate change scenarios based on two global climate models and two greenhouse gas emissions scenarios were evaluated.

We compared the impact of climate change by the 2050s to the impact of water withdrawals and dams on natural flow regimes that had occurred by 2002. Climate change was computed to alter seasonal flow regimes significantly (i.e. by more than 10\%) on $90 \%$ of the global land area (excluding Greenland and Antarctica), as compared to only one quarter of the land area that had suffered from significant seasonal flow regime alterations due to dams and water withdrawals. Due to climate change, the timing of the maximum mean monthly river discharge will be shifted by at least one month on one third on the global land area, more often towards earlier months (mainly due to earlier snowmelt). Dams and
\end{abstract}

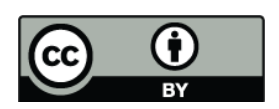

Correspondence to: P. Döll

(p.doell@em.uni-frankfurt.de) withdrawals had caused comparable shifts on less than $5 \%$ of the land area only. Long-term average annual river discharge is predicted to significantly increase on one half of the land area, and to significantly decrease on one quarter. Dams and withdrawals had led to significant decreases on one sixth of the land area, and nowhere to increases.

Thus, by the 2050s, climate change may have impacted ecologically relevant river flow characteristics more strongly than dams and water withdrawals have up to now. The only exception refers to the decrease of the statistical low flow $Q_{90}$, with significant decreases both by past water withdrawals and future climate change on one quarter of the land area. However, dam impacts are likely underestimated by our study. Considering long-term average river discharge, only a few regions, including Spain, Italy, Iraq, Southern India, Western China, the Australian Murray Darling Basin and the High Plains Aquifer in the USA, all of them with extensive irrigation, are expected to be less affected by climate change than by past anthropogenic flow alterations. In some of these regions, climate change will exacerbate the discharge reductions, while in others climate change provides opportunities for reducing past reductions. Emissions scenario B2 leads to only slightly reduced alterations of river flow regimes as compared to scenario A2 even though emissions are much smaller. The differences in alterations resulting from the two applied climate models are larger than those resulting from the two emissions scenarios. Based on general knowledge about ecosystem responses to flow alterations and data related to flow alterations by dams and water withdrawals, we expect that the computed climate change induced river flow alterations will impact freshwater ecosystems more strongly than past anthropogenic alterations.

Published by Copernicus Publications on behalf of the European Geosciences Union. 


\section{Introduction}

Climate change is impacting freshwater ecosystems not only by changing temperatures but also by changing water flow regimes. The term "flow regime" refers to the pattern of flow variability. Flow regimes are described by characteristics like long-term annual and monthly means, statistical low and high flows, daily to interannual variability, and the timing of flows. Many studies have shown that flow regimes play a major role in determining the biotic composition, structure, function and diversity within river ecosystems and that river flow alterations (and the resulting water storage changes e.g. in wetlands) may have a strong impact on freshwater ecosystems (Poff and Ward, 1989; Arthington and Pusey, 1993; Matthews and Marsh-Matthews, 2003; Poff and Zimmerman, 2010). Additionally, river flow alterations influence other abiotic characteristics of freshwater ecosystems that affect the well-being of organisms, in particular water quality, sediment transport and water temperature. Therefore, climate impact assessments should include an analysis of freshwater ecosystem changes that may be caused by climate change induced river flow alterations.

Most analyses of climate change impacts on freshwater ecosystems focused on the impact of temperature changes (Millenium Ecosystem Assessment, 2005; Fischlin et al., 2007). Some considered changes in mean precipitation, as a surrogate variable for river flows (Buisson et al., 2008; Lasalle and Rochard, 2009). Few analyses considered the effects of changing water flows. Kundczewicz et al. (2007) reviewed some publications that deal with the impacts of climate change induced river flow alterations on freshwater ecosystems, discussing decreased habitat availability due to decreased ice-jam flooding, impacts of lower water column depth on spawning of salmon, and impacts of reduced runoff on breeding grounds for water birds. In a review on the impact of climate and land use change on Alpine brown trout, Scheurer et al. (2009) concluded that climate change induced increases of river discharge and sediment loads in winter and early spring could be especially harmful for brown trout reproduction and development of young life stages. Erwin (2009) reflected on the challenges to wetland conservation and restoration under climate change, pointing out the need to reduce non-climate stressors, including monitoring, in particular of invasive species that are favored by climate change. He warned that a number of wetlands will disappear due to climate change, especially the drier-end wetlands. Assessing the impacts of climate change on waterbirds that depend on inland freshwater systems, Finlayson et al. (2006) also indicated semi-arid and arid regions as major vulnerable regions.

Climate change puts additional stress on freshwater ecosystems that have already been heavily stressed by human actions unrelated to climate change. Water withdrawals and man-made reservoirs have significantly modified river flow regimes (Döll et al., 2009). Other stresses on freshwater ecosystems include overexploitation, water pollution, habitat destruction or degradation (e.g. related to changes in fluvial morphology) and invasion by exotic species (Dudgeon et al., 2006). Their combined effects have led to declines in biodiversity that are by far greater than those in the most affected terrestrial ecosystems (Dudgeon et al., 2006). According to the Millennium Ecosystem Assessment (2005), populations of freshwater species (included in the Living Planet Index) declined, between 1970 and 2000, by 50\%, compared to $30 \%$ for marine and for terrestrial species. It is not possible to attribute the decline of freshwater ecosystems to the different stresses, which vary strongly with geographic region. Döll et al. (2009) found that river flow regime alterations are strongest in semi-arid regions with extensive irrigation but also downstream of large dams. In these regions, river flow alterations can be expected to be a major cause of biodiversity decline.

Investigating human impacts on river flow regimes in the 20th century and approaches for managing river basins in a sustainable manner, the importance of flow regimes for river ecosystems has been well documented (e.g. Richter et al., 2003). Renöfält et al. (2010) reviewed literature on ecosystem responses to flow alterations caused by hydropower generation, distinguishing flow magnitude, frequency, timing, duration and rate of change as well as changed waterlandscape interactions. According to Dudgeon et al. (2006), freshwater biodiversity is related to high flow events that influence the river channel shape and allow access to otherwise disconnected floodplain habitats, and to low flow events that limit overall habitat availability and quality. Many characteristics of the flow regime, in particular seasonality, interannual variability and timing of particular flow events, affect life-history patterns like spawning and recruiting (Dudgeon et al., 2006). Invasions by introduced or exotic species at the expense of native biota are more likely to succeed in an altered flow regime (if the former happen to be more adapted to the altered flow regime; Dudgeon et al., 2006). To characterize human alteration of freshwater ecosystems due to changed river flow regime in a satisfactory manner, a large number of data that allow relating freshwater biodiversity to specific flow regimes and regime alterations is required. However, knowledge of freshwater species is still very poor, in particular in developing countries, and it is not likely to significantly improve in the near future (Revenga et al., 2005). Based on an extensive literature review, Poff and Zimmerman (2010) concluded that existing literature on ecological responses does not allow deriving general quantitative relationships between flow alteration and ecological response. However, the literature does support the inference that the risk of ecological change increases with increasing magnitude of flow alteration (Poff and Zimmermann, 2010).

To assess ecologically relevant changes of river flow regimes, the Indicators of Hydrologic Alteration (IHA) approach of Richter et al. (1996) has been widely adopted or adapted (e.g. by Black et al., 2005). In this method, 
two sets of flow time series representing natural and anthropogenically altered conditions at the same site are compared using 32 indicators of flow magnitude, frequency, duration, timing and rate of change. Large differences between the indicators under natural and altered flow conditions are likely to indicate that the biotic components of the aquatic ecosystem have been altered too, with a reduction in endemic species and possibly a decline of biodiversity. Using a subset of IHA, Gibson et al. (2005) evaluated changes of the flow regimes in drainage basins in Florida and Washington that may have occurred by 2080-2095 due to climate change, and discussed their ecological significance. Statistically downscaled temperatures and precipitations of one climate model were used as input to the two hydrological models. In Florida, maximum flows were computed to decrease, reducing floodplain-river connectivity. In Washington, climate change may lead to a shift of the seasonal flow maximum from May to January, strongly decreased minimum flows, somewhat increased maximum flows, and a much prolonged low flow period from May to September. Prolonged low flows were considered to exacerbate higher future summer temperatures, with negative effects on cold-water fish, and to degrade the habitat. The computed changes in interannual variability were not considered to be reliable due to the low spatial resolution of the climate model (Gibson et al., 2005). The Tennant Method (Tennant, 1976), which has been applied for a reservoir outflow management in a large number of river, cannot be used for assessing the impact of altered flow regimes on freshwater ecosystems as it only refers to instantaneous flows but not to the ecologically relevant temporal sequences of flows, i.e. river flow regimes.

Obviously, a quantitative global-scale assessment of the impact of climate change on freshwater ecosystems related to river flow alterations cannot be done yet, due to missing quantitative estimates of ecosystem responses to alterations of the river flow regime. However, it is possible to do the first step of such an assessment, i.e. to perform a global-scale analysis of the alterations of the river flow regime that may be caused by climate change.

The objective of this study was to evaluate, for the first time, the impact of climate change on ecologically relevant flow characteristics at the global scale. To put these climate change impacts into perspective, future river flow alterations were compared to alterations of natural river flow that had already occurred by 2002 due to human water withdrawals and dams (Döll et al., 2009). We used the most recent version $2.1 \mathrm{~g}$ of the global hydrology and water use model WaterGAP (Alcamo et al., 2003; Hunger and Döll, 2008; Döll et al., 2009) which takes into account the impact of reservoirs and water withdrawals on river discharge. Two different emissions scenarios as interpreted by two state-of-the-art global climate models were applied to estimate river flow alterations that may have occurred by the 2050s as compared to the time period 1961-1990 when anthropogenic climate change was still small. Future changes of water withdrawals and dams were not taken into account. To illustrate possible ecological consequences of alterations of river flow alterations, we applied the empirically determined relationship between long-term average discharge at the mouth of river basins and number of endemic fish species of Xenopoulos et al. (2005), which was already used by Xenopoulos et al. for translating reduction of long-term average discharge due to climate change into reduction of the number of fish species.

In Sect. 2, we describe the methods to compute river flows for the climatic conditions of 1961-1990 and 2041-2070 (the 2050s) with and without the impact of water withdrawals and dams, and to compute the change of fish species numbers. In addition, we present the selected ecologically relevant indicators of river flow alteration. In Sects. 3 and 4, results are shown and discussed. In the last section, we summarize the study results and draw conclusions.

\section{Methods}

\subsection{Computation of river discharge with WaterGAP}

With a spatial resolution of $0.5^{\circ}$ by $0.5^{\circ}(55 \mathrm{~km}$ by $55 \mathrm{~km}$ at the equator), the global water resources and use model WaterGAP simulates water flows and storages (hydrology) as well as human water use for all land areas of the globe excluding Antarctica (Alcamo et al., 2003). Water use, i.e. water withdrawals and consumptive water use, is estimated by separate models for the sectors irrigation, livestock, households and industry. The WaterGAP Global Hydrology Model WGHM computes groundwater recharge, total runoff generation as well as river discharge, taking into account the impact of human water use and man-made reservoirs on river discharge (Döll et al., 2003; Döll and Fiedler, 2008). For each grid cell, the vertical water balance is computed, and the resulting runoff is routed laterally within the cell through a groundwater store and various surface water stores (if existent). The effect of lakes, reservoirs and wetlands on water balance and flow dynamics is modeled by first routing the runoff generated within the grid cell through so-called "local" lakes, reservoirs and wetlands. The resulting discharge volume is added to the discharge from the upstream grid cell and routed through so-called "global" lakes, reservoirs and wetlands, and through the river storage compartment. The difference between precipitation and potential evapotranspiration is added to each surface water type within the grid cell, thus taking into account the effect of the surface water balance on cell runoff. WGHM is tuned in a basin-specific manner against long-term average discharge at 1235 gauging stations (Hunger and Döll, 2008).

Important WGHM inputs are time series of monthly values of climate variables as well as information on soil and land cover. Monthly climate data are downscaled to daily data, in the case of precipitation using the available number of wet days per month. Monthly climate data, except precipitation, 
are provided by the CRU TS 2.1 data set (Mitchell and Jones, 2005). As precipitation input, $0.5^{\circ}$ gridded monthly time series of the GPCC Full Data Product Version 3 (Fuchs et al., 2007) were used, together with the number of wet days from the CRU TS 2.1 data set.

\subsubsection{Modeling the impact of water withdrawals and dams on river discharge}

In WGHM, the effect of human water withdrawals is simulated by subtracting total consumptive water use from river discharge and from water stored in lakes and reservoirs, if there are any in the grid cell. Consumptive use is the fraction of the withdrawn water that does not return to the river but is evapotranspirated, thus causing flow reductions. Consumptive use of a cell is supplied from the cell itself, or from the neighboring cell with the highest long-term average river discharge if not enough water is available in the cell itself. Domestic, industrial and livestock water use in 2002 was modeled by the respective WaterGAP water use modules. Irrigation water use was computed according to Döll and Siebert (2002) using, as input, 1) version 4.0.1 of the Global Map of Irrigated Areas GMIA (Siebert et al., 2005), 2) estimates of actually irrigated area per country in 2002 and 3) the climate data time series 1961-1990, to take into account the effect of climate variability on irrigation water use. While domestic, industrial and livestock water use is assumed to be constant within each year, irrigation water use varies from month to month. Global consumptive water use has more than doubled between 1951 and 2002 and reached $1300-1400 \mathrm{~km}^{3} / \mathrm{yr}$ around 2000 (as compared to renewable water resources of approximately $40000 \mathrm{~km}^{3} / \mathrm{yr}$ ), with irrigation accounting for more than $90 \%$ of total consumptive water use (Döll et al., 2009). Consumptive water use is particularly high in India, Pakistan, parts of China and the USA and in the Mediterranean region, mainly due to the large irrigation areas there (Döll et al., 2009).

The impact of dams on river discharge is computed in this study by using a reservoirs and regulated lakes data set that includes 6553 reservoirs and 52 regulated lakes worldwide. The surface area of the reservoirs is $291000 \mathrm{~km}^{2}$, the storage capacity $5900 \mathrm{~km}^{3}$ (Döll et al., 2009). The data set was obtained by combining mainly the reservoirs included in the Global Lakes and Wetlands Database (Lehner and Döll, 2004) with a preliminary (July 2008) version of the GRanD database (Lehner et al., 2008, 2010) The 1022 largest reservoirs and all the regulated lakes are modeled using a specific algorithm for reservoirs, distinguishing two types of reservoirs, irrigation and non-irrigation (Döll et al., 2009). The other reservoirs are modeled like natural lakes. The majority of reservoirs are in North America and Asia.

\subsubsection{Modeling the impact of climate change on river discharge}

We considered four different climate change scenarios, comparing the flow regime resulting from the climate during the time period 1961-1990 to the flow regime during the time period 2041-2070 (the 2050s). The two IPCC greenhouse gas emissions scenarios A2 and B2 (Nakicenovic and Swart, 2000) were translated into climate change scenarios by two state-of-the-art global climate models, the ECHAM4/OPYC3 model (Röckner et al., 1996, hereafter referred to as ECHAM4) and the HadCM3 model (Gordon et al., 2000). In the $\mathrm{A} 2$ scenario, emissions increase from $11 \mathrm{Gt} \mathrm{C} / \mathrm{yr}\left(\mathrm{CO}_{2}\right.$-equivalent) in 1990 to $25 \mathrm{GtC} / \mathrm{yr}$ in the 2050 s, but only to $16 \mathrm{Gt} \mathrm{C} / \mathrm{yr}$ in the case of scenario B2. Due to large climate model uncertainties, the same emissions scenarios are translated to rather different climate scenarios, in particular with respect to precipitation.

The changes in averages of monthly precipitation and temperature values between the periods 1961-1990 and 20412070 as computed by the climate models were used to scale the grid cell values of observed monthly precipitation and temperature between 1961 and 1990 that drive WGHM in the control run. In a first step, the climate model data were linearly interpolated from their original resolutions to the WGHM resolution of $0.5^{\circ}$. Then, in the case of temperature, observed values were scaled by adding to them the difference of the climate model values of future (2041-2070) and present-day (1961-1990) temperature. The 30-year perturbed precipitation time series was produced by multiplying observed values with future climate model precipitation as a ratio of the present-day precipitation. If present-day monthly precipitation was less than $1 \mathrm{~mm}$, precipitation was scaled additively, like temperature. The impact of changed interannual variability and the predicted increased variability of daily precipitation could not be taken into account in this study.

\subsubsection{Specification of model runs}

Six 30-year time series of gridded monthly river discharge were computed by WHGM, which were then used to quantify the indicators of river flow regime alterations described in Sect. 2.2. In our analysis, ANT conditions refer to the flow regime as impacted by human water withdrawals as well as by reservoirs and regulated lakes for the climate of the years 1961-1990, with withdrawals and dams in 2002. This simulation is the standard WGHM simulation for which tuning against long-term annual observed discharge has been performed. NAT refers to the naturalized regime as computed by a model run in which there are no water withdrawals and no reservoirs, and in which regulated lakes are treated like natural lakes. CC-ANT refers to any of the four ANT model runs with climate of the years 2041-2070 which differ by 
Table 1. Five ecologically relevant indicators of river flow alterations due to climate change or human water withdrawals and reservoirs. The term "altered" either refers to alterations due to climate change (CC-ANT), as compared to the climate of 1961-1990 ("unaltered"=ANT), or to alterations due to water withdrawals and dams, for 1961-1990 climate (ANT), as compared to naturalized conditions without any dams and withdrawals ("unaltered"=NAT).

\begin{tabular}{|c|c|c|c|}
\hline indi-cator & question & definition & specific ecological relevance $^{\mathrm{a}}$ \\
\hline$I_{\mathrm{LTA}}$ & $\begin{array}{l}\text { How are long-term } \\
\text { average river flows } \\
\text { affected? }\end{array}$ & $\begin{array}{l}\text { differences between long-term average annual } \\
\text { river discharges under altered and unaltered } \\
\text { conditions, in percent of long-term average un- } \\
\text { altered river discharge }\end{array}$ & $\begin{array}{l}\text { number of endemic fish species, } \\
\text { groundwater-dep. floodplain } \\
\text { vegetation }\end{array}$ \\
\hline$I_{\mathrm{LF}}$ & $\begin{array}{l}\text { How are statistical } \\
\text { low flows affected? }\end{array}$ & $\begin{array}{l}\text { difference between long-term average } Q_{90} \\
\text { (monthly river discharge that is exceeded in } 9 \\
\text { out of } 10 \text { months) under altered and non-altered } \\
\text { conditions, in percent of unaltered } Q_{90}\end{array}$ & $\begin{array}{l}\text { habitat conditions, like temper- } \\
\text { ature and oxygen concentra- } \\
\text { tion, connectivity, compatibil- } \\
\text { ity with life cycle of organisms, } \\
\text { wastewater dilution }\end{array}$ \\
\hline$I_{\mathrm{SA}}$ & $\begin{array}{l}\text { How is the seasonal } \\
\text { amplitude affected? }\end{array}$ & $\begin{array}{l}\text { difference in seasonal amplitude (maximum mi- } \\
\text { nus minimum long-term average monthly river } \\
\text { discharge) under altered and unaltered condi- } \\
\text { tions, in \% of unaltered amplitude }\end{array}$ & $\begin{array}{l}\text { habitat availability in particular } \\
\text { on floodplains, increase in non- } \\
\text { natives }\end{array}$ \\
\hline$I_{\mathrm{SR}}$ & $\begin{array}{l}\text { How is the seasonal } \\
\text { regime affected? }\end{array}$ & $\begin{array}{l}\text { mean over } 12 \text { monthly values of absolute differ- } \\
\text { ences between long-term average monthly river } \\
\text { discharges under altered and unaltered condi- } \\
\text { tions, in } \% \text { of unaltered discharge }\end{array}$ & $\begin{array}{l}\text { habitat conditions, compatibil- } \\
\text { ity with life cycle of organisms }\end{array}$ \\
\hline$I_{\mathrm{TS}}$ & $\begin{array}{l}\text { What seasonal flow } \\
\text { shifts (will) have } \\
\text { occurred? }\end{array}$ & $\begin{array}{l}\text { temporal shift of month with maximum river } \\
\text { discharge, in months (if negative, this month oc- } \\
\text { curs earlier due alteration) }\end{array}$ & $\begin{array}{l}\text { compatibility with life cycle of } \\
\text { organisms, e.g. disruption } \\
\text { of spawning, assemblage struc- } \\
\text { ture, food availability for detri- } \\
\text { tivorous macroinvertebrates }\end{array}$ \\
\hline
\end{tabular}

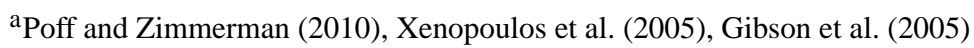

the climate scenarios. In the CC-ANT runs, withdrawals and dams remain at the 2002 level.

\subsection{Indicators of river flow regime alteration}

In our global-scale study on the impact of water withdrawals and dams on river flow regimes, we developed six different indicators of river flow regime alteration that are ecologically relevant and can be computed by WGHM in a rather reliable manner (Döll et al., 2009). Five out of the six indicators are also used here (Table 1). The indicator related to interannual variability of monthly flows was not suitable for this study because in our method for deriving climate scenarios (Sect. 2.1.2), changes of interannual variability as computed by climate model are not represented, only changes of longterm average monthly precipitation and temperature.

\subsection{Estimation of changes of freshwater fish richness due to changes in long-term average river discharge}

Xenopoulos et al. (2005) derived a regression equation between the number of freshwater species in river basins and the long-term average river discharges (1961-1990) at the mouth of the basins. They considered data from 237 river basins located between $42^{\circ} \mathrm{N}$ and $42^{\circ} \mathrm{S}$. The number of fish species mainly relates to endemic fish, with nonindigenous species being assumed to be less than 5\%. Long-term average discharge was computed with a previous version of WGHM (Xenopoulos et al., 2005). Fish species numbers in river basins were found to decrease with decreasing longterm average river discharge according to

Log number of fish species in basin $=$

$0.4 \cdot \log$ mean annual discharge at basin outlet $\left(\mathrm{m}^{3} / \mathrm{s}\right)$

$$
+0.6242, r^{2}=0.57
$$

Xenopolous et al. (2005) used Eq. (1) to compute decreases of fish species richness in zero-order river basins for which 
ECHAM4 A2

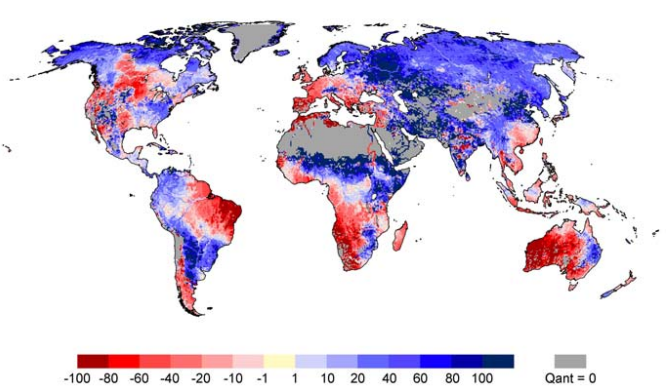

ECHAM4 B2

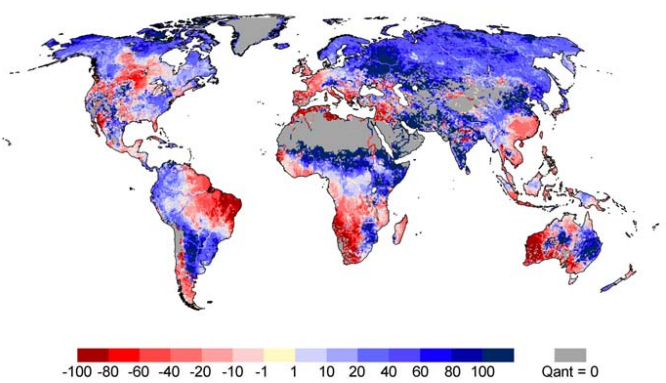

HadCM3 A2

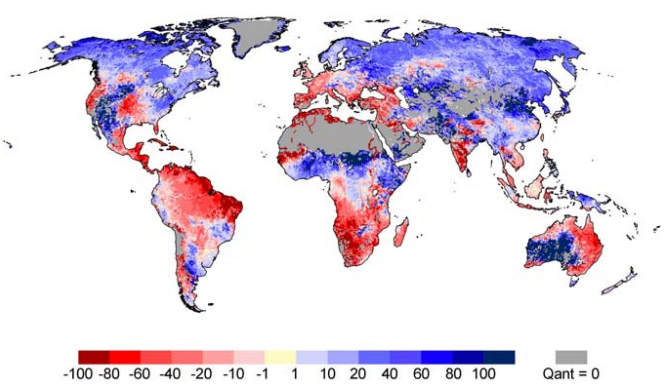

HadCM3 B2

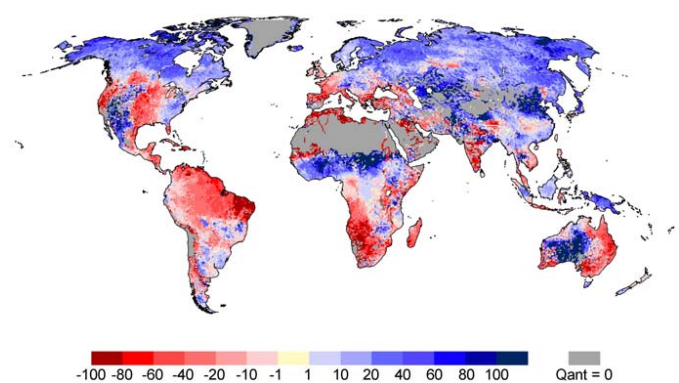

Fig. 1. Impact of climate change on river discharge: change of monthly low flows $Q_{90}, I_{\mathrm{LF}}$, between 1961-1990 and 2041-2070. Emissions scenarios A2 and B2 as implemented by the global climate models ECHAM4 and HadCM3, river flows anthropogenically altered due to water withdrawals and reservoirs of the year 2002 (CC-ANT - ANT, in \% of ANT).

river discharge at the river mouth was predicted to decrease due to future climate change and future water withdrawals. They stated that the consequences of increasing river discharge for riverine biodiversity have not been rigorously tested and thus did not apply Eq. (1) for river basins with future discharge increases. Following Xenopoulos et al. (2005), we only applied Eq. (1) in case of decreasing discharge. Different from Xenopoulos and colleagues, we determined the decrease of endemic fish species (at equilibrium) in the upstream basin of each $0.5^{\circ}$ grid cell, not only for whole zero-order basins.

\section{Results}

In this section, the computed impact of climate change on river flow regimes is presented, and then compared to the impact of dams and water withdrawals on the natural flow regime. In the last part, we show the possible impact of decreased long-term average river discharge on the number of fish species, as quantified by applying Eq. (1).

\subsection{Impact of climate change on five ecologically relevant river flow characteristics}

Figure 1 shows the impact of four different climate change scenarios on statistical monthly low flows $Q_{90}$ (indicator $I_{\mathrm{LF}}$ in Table 1) by the 2050s, by comparing CC-ANT with ANT. $Q_{90}$ is monthly river discharge that is exceeded in 9 out of 10 months. In all scenarios, the spatial pattern of increasing or decreasing $Q_{90}$ is roughly the same, except in Australia and South America, where strong discrepancies between the ECHAM4 and HadCM3 scenarios exist. $Q_{90}$ is predicted to decrease, in all scenarios, very strongly by more than $80 \%$ in Northeastern Brazil, the western part of Southern Africa and at the Mediterranean rim, while it may increase by more than $100 \%$ in Northeastern China. The B2 scenarios, with lower emissions, result in somewhat less intensive changes than the A2 scenarios. It is obvious, however, that the translation of the same emissions scenario by two climate model results in larger differences than if one climate model is used to translate the two different emissions scenarios. Particular discrepancies between the two climate models are clearly visible in Australia, India, West Africa and South America, with HadCM3 predicting a dryer future for the same emissions scenario than ECHAM4. Both climate models can be regarded as equally uncertain. The difference between the projections of the two climate models illustrates only a fraction of the uncertainty. Selecting other climate models as input to WGHM will probably lead to a still larger range of projected patterns of $Q_{90}$. 
Table 2. Global characterization of river flow regime alteration due to climate change until the 2050s, as compared to historic climate 1961-1990, and due to water withdrawals and reservoirs around the year 2000, as compared to naturalized conditions. In the "CC-ANT compared to ANT" columns, the change in river flow regimes between 1961-1990 and 2041-2070 is shown, assuming water withdrawals and reservoirs representative for the year 2000. As climate scenarios, the A2 emissions scenario as interpreted by the global climate models ECHAM4 and HadCM3 were used. In the "ANT compared to NAT" columns, the impact of water withdrawals and dams for the climate 1961-1990 is shown. Greenland and Antarctica are not taken into account. In columns with "+" header, the percent of land area in which the indicator is at least $10 \%$ (or one month) is shown, in columns with "-" header, the percent of land area in which indicator is minus $10 \%$ or smaller (or minus one month).

\begin{tabular}{|c|c|c|c|c|c|c|c|c|c|c|c|c|}
\hline \multirow[b]{4}{*}{ Indicator } & \multicolumn{6}{|c|}{$\begin{array}{c}\% \text { of land area with indicator value } \geq|10 \%| \\
\left.\text { (or } \geq \mid 1 \text { month } \mid, \text { in case of indicator } I_{\mathrm{TS}}\right)\end{array}$} & \multicolumn{6}{|c|}{$\begin{array}{l}\text { median of indicator values for these land } \\
\text { areas, in \% (for indicator } I_{\mathrm{TS}} \text { in months) }\end{array}$} \\
\hline & \multicolumn{4}{|c|}{ CC-ANT compared to ANT } & \multirow{2}{*}{\multicolumn{2}{|c|}{$\begin{array}{l}\text { ANT compared } \\
\text { to NAT }\end{array}$}} & \multicolumn{4}{|c|}{ CC-ANT compared to ANT } & \multirow{2}{*}{\multicolumn{2}{|c|}{$\begin{array}{l}\text { ANT compared } \\
\text { to NAT }\end{array}$}} \\
\hline & \multicolumn{2}{|c|}{ ECHAM4 A2 } & \multicolumn{2}{|c|}{ HadCM3 A2 } & & & \multicolumn{2}{|c|}{ ECHAM4 A2 } & \multicolumn{2}{|c|}{ HadCM3 A2 } & & \\
\hline & + & - & + & - & + & - & + & - & + & - & + & - \\
\hline$I_{\mathrm{LTA}}$ & 54.4 & 23.1 & 49.9 & 23.8 & 0.002 & 16.2 & 44.9 & -27.6 & 29.2 & -29.3 & 19.8 & -27.9 \\
\hline$I_{\mathrm{LF}}$ & 45.8 & 24.3 & 39.9 & 27.0 & 4.9 & 26.0 & 40.4 & -33.7 & 27.7 & -33.6 & 63.2 & -52.5 \\
\hline$I_{\mathrm{SA}}$ & 55.9 & 26.1 & 53.5 & 23.5 & 0.6 & 14.8 & 56.2 & -30.2 & 40.1 & -26.6 & 17.2 & -33.5 \\
\hline$I_{\mathrm{SR}}^{\mathrm{a}}$ & \multicolumn{2}{|c|}{89.8} & \multicolumn{2}{|c|}{88.5} & \multicolumn{2}{|c|}{23.8} & \multicolumn{2}{|c|}{46.3} & \multicolumn{2}{|c|}{34.0} & \multicolumn{2}{|c|}{3.3} \\
\hline$I_{\mathrm{TS}}$ & 14.3 & 25.1 & 12.1 & 20.7 & 2.7 & 1.7 & 1 & -1 & 1 & -1 & 1 & -1 \\
\hline
\end{tabular}

a indicator has absolute values.

For the A2 emissions scenario, $Q_{90}$ is predicted to increase significantly, i.e. by more than $10 \%$, on $40-46 \%$ of the land area (excluding Antarctica and Greenland), the median increase in these areas being $28-40 \%$ (Table 2). The ranges reflect the different results due to the two applied climate models. The median values in Table 2 always refer to the indicated area with significant changes. $Q_{90}$ decreases by more than $10 \%$ on $24-27 \%$ of the land area, by a median of $34-34 \%$ (Table 2). For the B2 scenarios, $Q_{90}$ is predicted to increase significantly on $38-47 \%$ of the land area (with a median increase of $27-41 \%$ ) and to decrease on $21-26 \%$ of the land area (with a median decrease of 30-32\%) (not shown in Table 2). This indicates that reduced emissions have a rather small beneficial effect on climate change induced low flow reductions.

Long-term average annual discharges (indicator $I_{\text {LTA }}$ ) show approximately the same spatial pattern as $I_{\mathrm{LF}}$, with somewhat larger areas with flow increases and higher percent increases. (Fig. 2a, emissions scenario B2). For A2, longterm average river discharge is predicted to increase by more than $10 \%$ on $49-54 \%$ of the land area, by on average 29$45 \%$ (median), while it decreases by more than $10 \%$ on $23-$ $24 \%$ of the land area, by on average $24-29 \%$. The change in seasonal amplitudes (indicator $I_{\mathrm{SA}}$ ) correlates strongly with $I_{\text {LTA }}$ (Fig. 2b and Table 2). One of a few exceptions occurs, in the HadCM3 B2 scenario, in the upstream part of the Amazon basin where seasonal amplitude increases even though long-term average discharge decreases (compare Fig. 2a with Fig. 2b).
Changes of the seasonal regime (computed as the average difference of the 12 mean monthly river discharges, indicator $\left.I_{\mathrm{SR}}\right)$ are more pronounced for the ECHAM4 run than for the HadCM3 run (Fig. 2c and Table 2). Mean monthly discharges change by more than $10 \%$ (averaged over the 12 months) on about $90 \%$ of the global land area in case of scenario A2 (Table 2). In these areas, the median change is $34-46 \%$, depending on the climate model. The month with the maximum monthly river discharge (indicator $I_{\mathrm{TS}}$ ) is expected to shift by at least 1 month on 33-39\% of the land area, more often to earlier months (Table 2). The earlier maximum flow is mostly related to earlier snowmelt. The median value is 1 month, but there are a significant number of grid cells with shift of 2 or even 3 to 6 months (Fig. 2d).

\subsection{Comparison of climate change impacts to impacts of dams and water withdrawals}

Compared to the impacts that dams and water withdrawals had on natural river discharges by 2002, climate change will have led, by the 2050s, to much stronger alterations of the selected ecologically relevant flow characteristics. Different from climate change, dams and withdrawals nowhere led to any increases of long-term average discharge (Fig. 3a, and indicator $I_{\text {LTA }}$ in Table 2). They resulted in significant decreases of long-term average river discharge on $16 \%$ of the global land area, while climate change is predicted to cause decreases on $23-24 \%$. It is further predicted to cause significantly increased long-term average discharge on about half of the land area (Fig. 3b and Table 2). Thus, changes between CC-ANT and NAT, i.e. the impacts of dam, reservoirs and climate change on naturalized long-term average river 
ECHAM4 B2

a

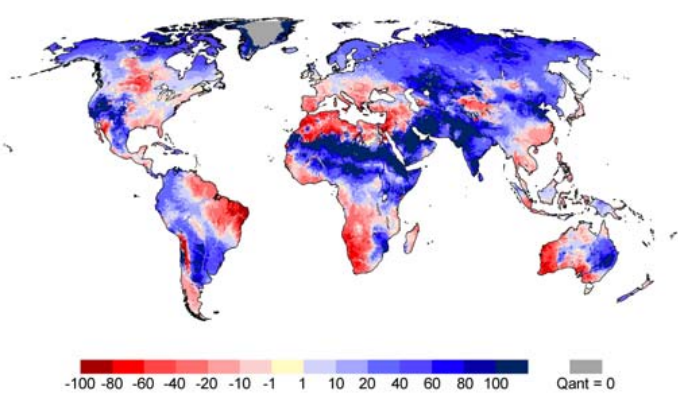

b

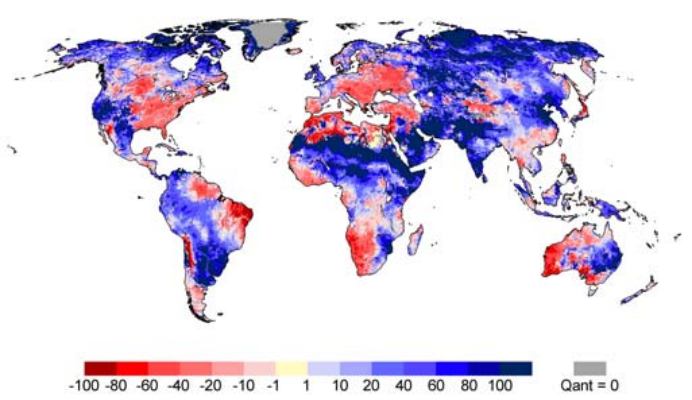

C

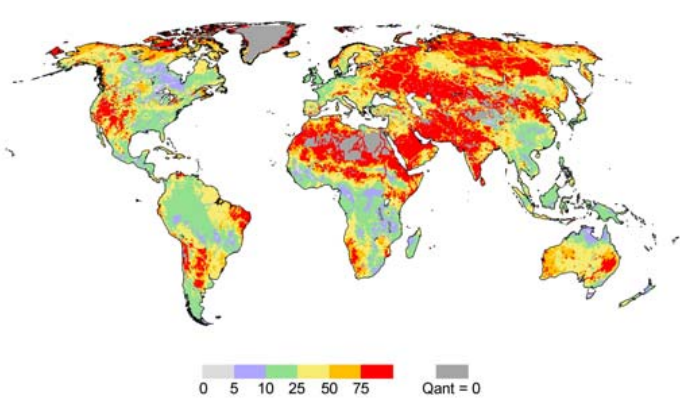

d

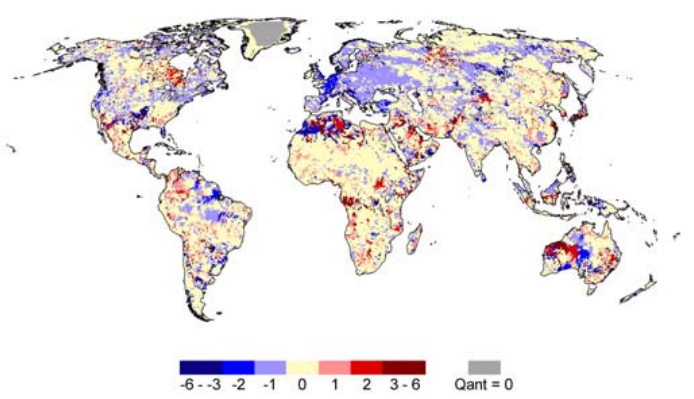

HadCM3 B2
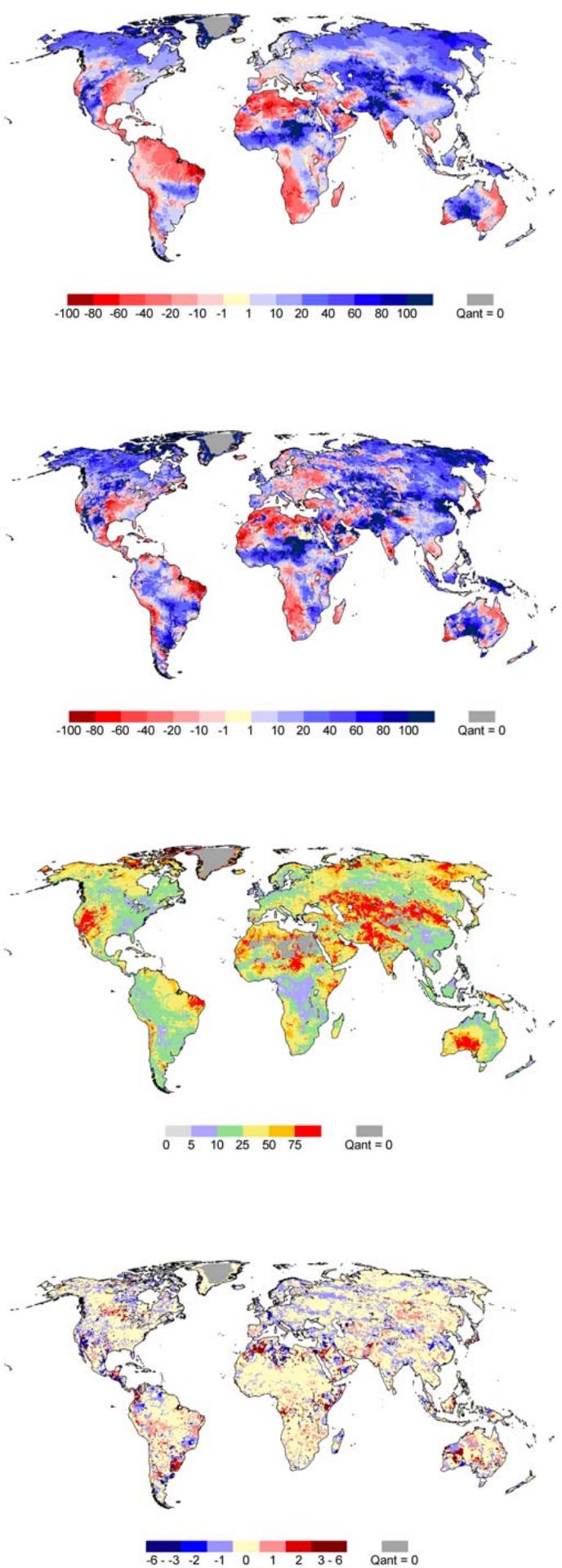

Fig. 2. Impact of climate change on river discharge: percent change of long-term average annual river discharge, $I_{\text {LTA }}$ (a), seasonal flow amplitudes, $I_{\mathrm{SA}}(\mathbf{b})$, seasonal flow regimes, $I_{\mathrm{SR}}(\mathbf{c})$ and shift of the month with maximum flow, $I_{\mathrm{TS}}$, in months (d), between $1961-1990$ and 2041-2070. Emissions scenario B2 as implemented by the global climate models ECHAM4 and HadCM3, river flows anthropogenically altered due to dams and water withdrawals of the year 2002 (CC-ANT - ANT, in \% of ANT). 
a

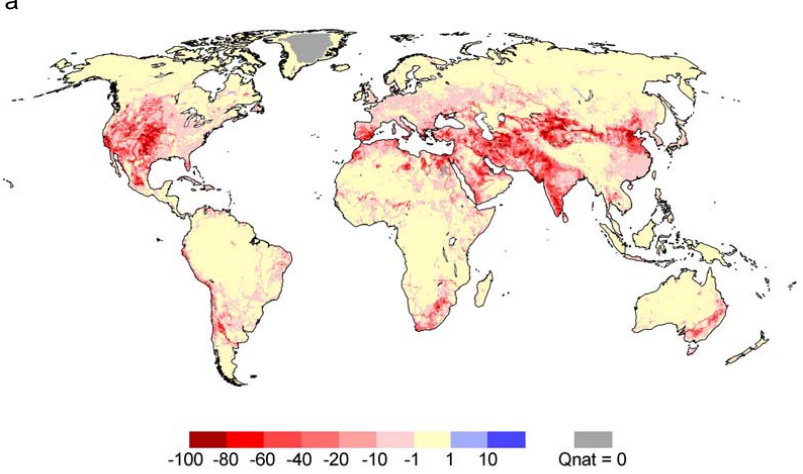

b

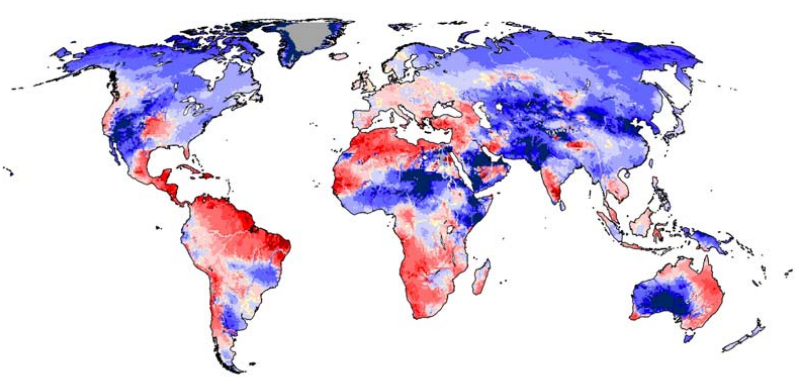

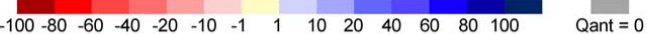

C

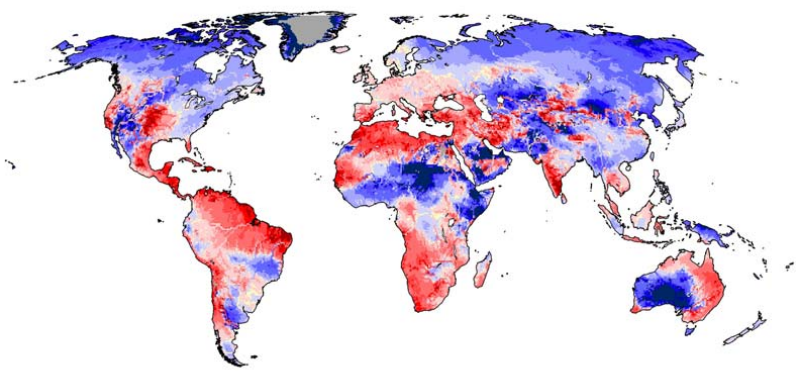

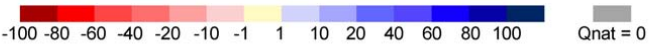

Fig. 3. Comparison of the impact of climate change to the impact of dams and water withdrawals with respect to long-term average annual river discharge $\left(I_{\text {LTA }}\right)$. Impact of dams and withdrawals on naturalized discharge (ANT - NAT, in \% of NAT) (a), impact of climate change on anthropogenically altered discharge (CC-ANT - ANT, in \% of ANT) (b), combined impact of climate change, dams and water withdrawals (CC-ANT - NAT, in \% of NAT) (c). Dams and withdrawals in the year 2002, climate change between 1961-1990 and 2041-2070 according to the emissions scenario A2 as implemented by the global climate model HadCM3.

discharge (Fig. 3c), are more pronounced than changes between CC-ANT and ANT (Fig. 3b) only if climate change leads to decreased long-term average discharges.

Alteration of all flow characteristics is much stronger in the case of climate change than in the case of past anthro- pogenic change by dams and water withdrawals, with one exception (Table 2 and Fig. 4 and; $I_{\text {SA }}$ not shown in Fig. 4). The exception is $I_{\mathrm{LF}}$ (Fig. $4 \mathrm{a}$ and b). While climate change causes more wide-spread increases of $Q_{90}$ than dams, the areal extent with significant decreases by more than $10 \%$ is comparable. While climate change will cause such decreases on 21-27\% (range of all four scenarios) of the global land area, dams and withdrawals caused such a decline of natural low flows on $26 \%$ of the land area (Table 2). The average (median) decrease due to dams and withdrawals in these areas was $53 \%$, significantly larger than the average decrease due to climate change (30-34\%).

Figuer 5 indicates, in red, all areas where the impact of climate change on long-term average river discharge (Fig. 5a) or $Q_{90}$ (Fig. 5b) is at least twice as large as the impact of dams and withdrawals. The intensive red color marks the areas where changes due to dams and reservoirs have the same sign as the changes due to climate change. In blue, areas in which the impact of dams and reservoirs is twice as big as the impact of climate change are indicated. Considering longterm average river discharge, only a few areas, including Spain, Italy, Iraq, Southern India, Western China, the Australian Murray Darling Basin and the High Plains Aquifer in the USA, all of them with significant irrigation, show a dominance of past alterations (Fig. 5a). Considering $Q_{90}$, there are many more areas in which past river flow alterations due to dams and withdrawals dominate over climate change impacts, including most parts of the USA, the Mediterranean and Western and South Asia (Fig. 5b). Low flows are more sensitive to dams and withdrawals than long-term average river discharges.

\subsection{Impact of climate change on number of fish species}

Relating changes of long-term average discharge to changes in fish species number using Eq. (1), we computed the impact of climate change on the number of endemic fish species (at equilibrium) in the upstream basin of each grid cell (Fig. 6b, HadCM3 A2). In the HadCM3 A2 scenario, $15 \%$ of the global land area would suffer from a decrease of fish species in the upstream basin of more than $10 \%$, and $0.6 \%$ of the land from a decrease of even $50 \%$. The median decrease of fish species in areas with a more than $10 \%$ decrease is 18.3\%. As the HadCM3 predicts significant discharge decreases in Central America and the northern part of South America (more pronounced than the ECHAM4 model, compare Fig. 2a and b), significant decreases of fish species richness are visible there, which, given the high number of endemic fish in these regions, would mean the loss of many fish species. For example, the number of fish species in the Amazon basin (affected by dams and withdrawals of the year 2002) is computed to decrease from 561 under climate conditions of 1961-1990 to 511 in 2041-2070. The corresponding numbers for the Orinoco are 279 and 232, and 191 and 159 for the Tocantins (Brazil). For two zero-order 
ANT - NAT

1961-1990

a

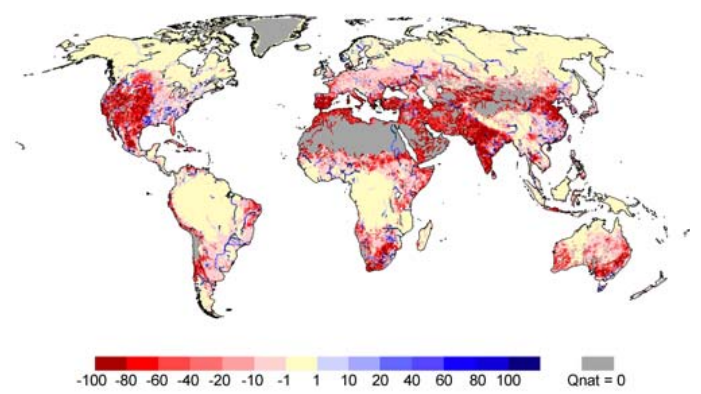

C

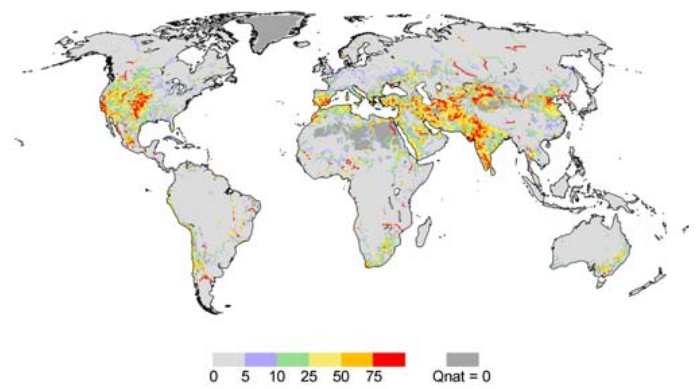

e

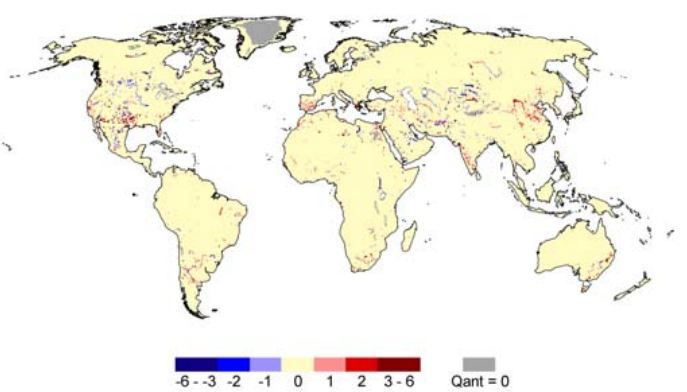

CC-ANT - ANT

2041-2070

b

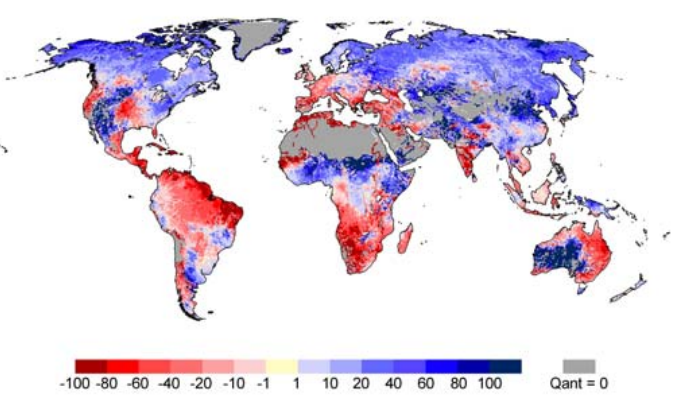

d

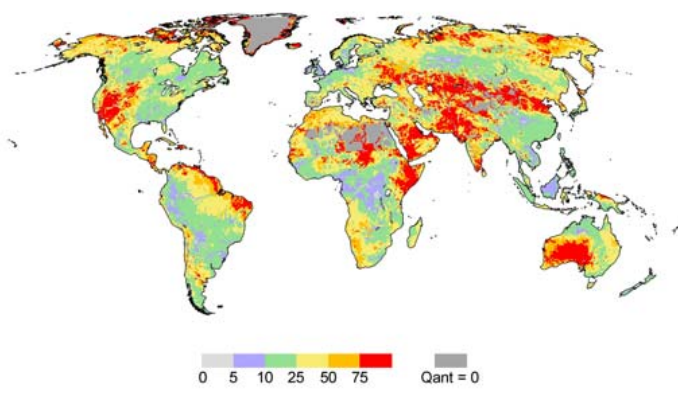

f

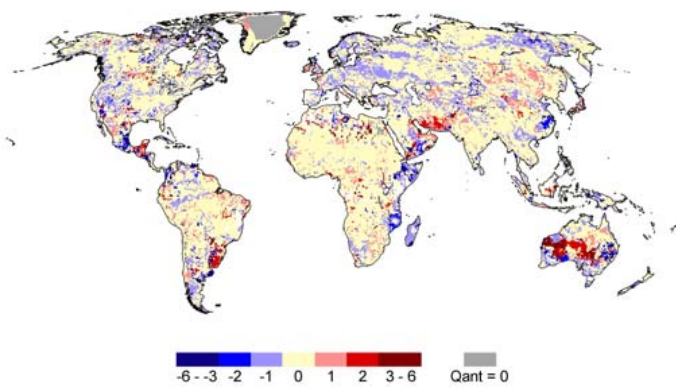

Fig. 4. Comparison of the impact of climate change to the impact of dams and water withdrawals. Impact of dams and withdrawals on naturalized discharge (ANT - NAT, in $\%$ of NAT), for monthly low flows $Q_{90}, I_{\mathrm{LF}}(\mathbf{a})$, seasonal flow regimes, $I_{\mathrm{SR}}(\mathbf{c})$, and shift of the month with maximum flow, $I_{\mathrm{TS}}(\mathbf{e})$, as compared to impacts of climate change on anthropogenically altered discharge (CC-ANT - ANT, in $\%$ of ANT), for monthly low flows $Q_{90}$ (b), seasonal flow regimes (d), and shift of the month with maximum flow (f). Dams and withdrawals in the year 2002, climate change between 1961-1990 and 2041-2070 according to the emissions scenario A2 as implemented by the global climate model HadCM3.

rivers in the semi-arid Northeast of Brazil, the situation appears to be more dramatic. The number of fish species in the Parnaíba river basin may decrease from 66 to 24, and in the Jaguaribe river basin from 36 to 1 . Please note that these fish numbers were computed from Eq. (1) and can only be considered to be very rough estimates. In the Amazon and the Orinoco, for example, the number of endemic (endemic plus non-endemic) fish species was estimated to be 1800 (3000) and 88 (318), respectively ("Watersheds of the World: A Special Collection of River Basin Data", http: //earthtrends.wri.org/maps_spatial/watersheds/index.php).

Globally, the decrease of riverine fish species richness due to climate change is stronger than the decrease due to dams and withdrawals, which caused a decrease of the number of fish species in the upstream basin by at least $10 \%$ on $10 \%$ of the land area, while on $0.6 \%$, it caused a decrease of more than $50 \%$ (Fig. 6a). The spatial patterns of change are very different (comp. Fig. 6a and b), with climate change possibly 
a

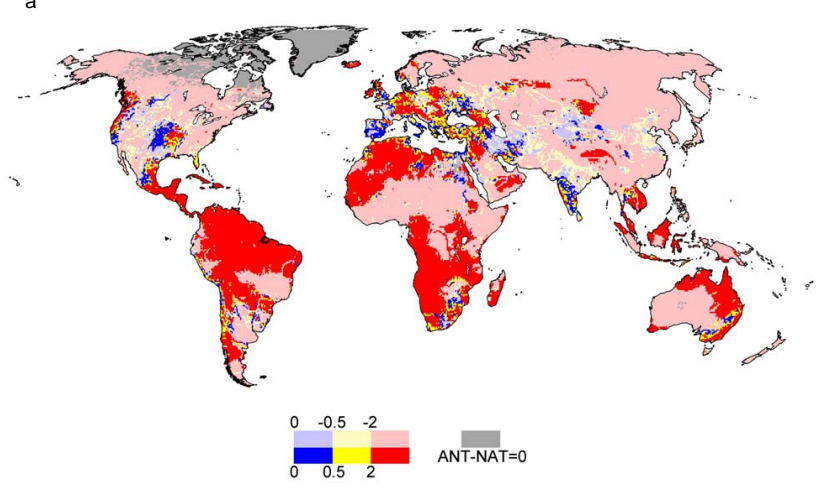

b

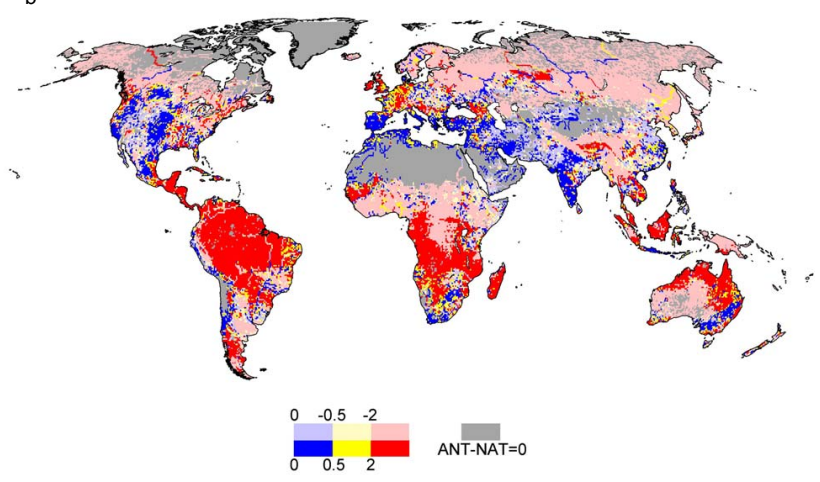

Fig. 5. Comparison of the impact of climate change to the impact of dams and water withdrawals, expressed as (CC-ANT ANT)/(ANT - NAT), for long-term average annual discharge, $I_{\mathrm{LTA}}$ (a) and monthly low flows $Q_{90}, I_{\mathrm{LF}}$ (b). Red colors indicate that the climate change affects the two flow variables at least twice as much as dams and water withdrawals do, blue colors the opposite. Positive values indicate the changes due to climate change and withdrawal and dams are either both negative or both positive. Dams and withdrawals in the year 2002, climate change between 1961-1990 and 2041-2070 according to the emissions scenario A2 as implemented by the global climate model HadCM3.

causing strong decreases in hitherto unaffected regions like Central and South America, for example.

\section{Discussion}

\subsection{Computation of decreases of the number of fish species due to decreased long-term average river discharge}

We used Eq. (1) to estimate decreases of endemic fish species numbers upstream of each $0.5^{\circ}$ grid cell. This interpretation of Eq. (1) differs from Xenopoulos et al. (2005), who used the equation to only compute one value for each zero-order river basin. As Eq. (1) was derived by relating long-term average river discharge at a certain point in a river to fish species numbers upstream of that point, we think that our a

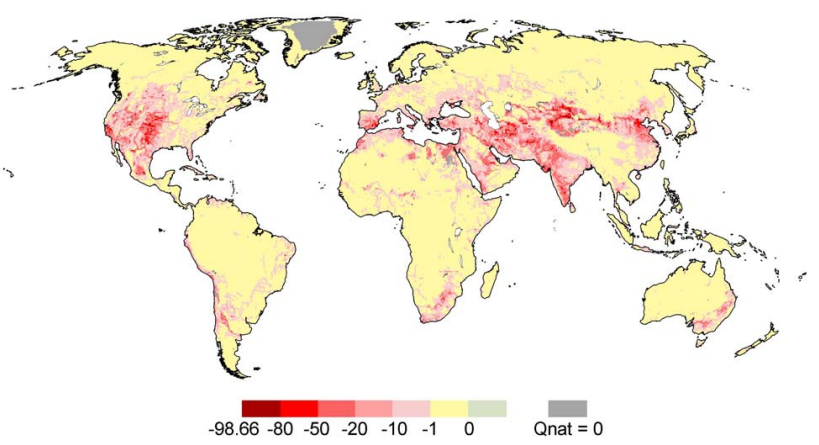

b

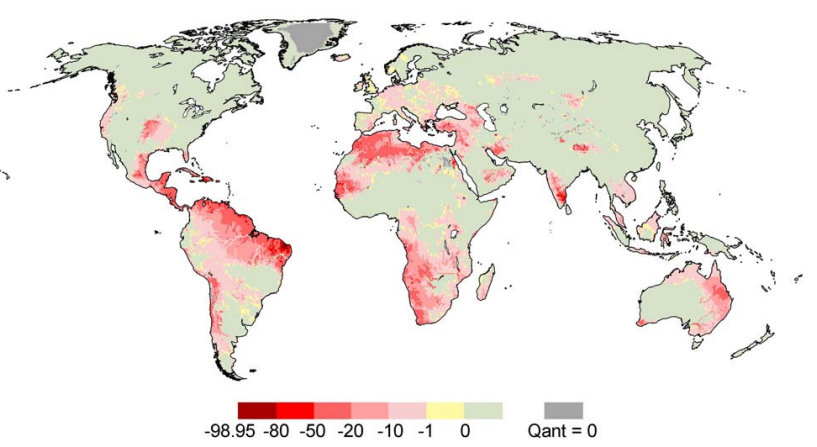

Fig. 6. Impacts on number of fish species. Impact of dams and withdrawals on number of fish species upstream of grid cells (ANT - NAT, in \% of NAT) (a), and impact of climate change on number of fish species upstream of grid cells (CC-ANT - ANT, in \% of ANT) (b). Withdrawals and dams in the year 2002, climate change between 1961-1990 and 2041-2070 according to the emissions scenario A2 as implemented by the global climate model HadCM3.

interpretation of the regression equation provides an appropriate, spatially more detailed and therefore more informative geographical representation of the quantitative relation between flow and ecological response. However, for three rivers in the Pacific Northwest of the USA, McGarvey and Hughes (2008) found that it is preferable to derive speciesdischarge relationships not for whole river basins but for individual reaches if distinct fish assemblages exist.

In our scenarios of the 2050s, we kept dams and water withdrawals at the 2002 level. We expect that the impact of climate change on river flow will be exacerbated by future increases of dams and water withdrawals in many regions. Comparing computed climate change scenarios of river fish species losses with and without changes in water withdrawals, Xenopoulos et al. (2005) found that for the considered river basins, climate change was by far the most important driver of change, with the exception of Euphrates/Tigris, Sacramento and Rio Grande. In the other basins, increased water withdrawals only added fish species losses of $0-5 \%$ to the climate change induced losses. 
The computed decreases of fish species richness should be regarded as indicative only, because changes in long-term average discharge are the only characteristics of the river flow regime that are modeled to affect fish species numbers. While long-term average discharge certainly correlates with other ecologically relevant flow characteristics like low and high flows, we have seen that climate change impacts do vary among them, for example, between long-term average discharge and low flow $Q_{90}$. Furthermore, Eq. (1) has not been tested for its predictive capability. Xenopoulos et al. (2005) concluded that fish species losses as predicted by Eq. (1) are likely to underestimate actual future discharge-related species losses due to, for example, a loss of connectivity to flood plains or increased pollutant concentrations due to decreased water volumes. Regarding ecological consequences of increased river discharge, Xenopolous et al. (2005) noted that the consequences of increased discharge on fish species richness are highly uncertain, but that increases of discharge might allow the establishment of new non-indigenous species if they were introduced by humans. Poff and Zimmerman (2010), however, identified consistent negative fish responses not only to decreased but also to increased average discharges.

\subsection{Model validity and climate change impacts for selected river basins}

In Döll et al. (2009), we discussed how well WGHM is able to simulate the impact of dams and withdrawals on river discharge, looking at observed data before and after the construction of a dam, or independent estimates of naturalized discharges. We concluded that for many rivers, the impact of humans on river discharge can be simulated by WGHM reasonably well, even though the magnitude of alteration was underestimated in case of the rivers that we analyzed. Such a validation is not possible for river flow alterations that are computed to occur due to future climate change. Therefore, in Fig. 7, we only show how well observed anthropogenically altered mean monthly river discharges for the climate 1961-1990 (but withdrawals as of the year 2002) fit to observed river discharges at three stations (comp. ANT to obs in Fig. 7). We also show the computed impact of dams and withdrawals (comp. ANT to NAT), and the computed impact of climate change until 2055 for the four different scenarios (comp. CC-ANT to ANT). We selected the stations Vadu-Oii-Hirsova (Danube), Hermann (Missouri) and Volgograd (Volga) because flow regimes have already been altered there, and climate change will lead to either decreasing, approximately constant and increasing long-term average river discharge.

In the Danube basin, WGHM strongly underestimates observed winter discharges, which might be due to an underestimation of rain or snowmelt in the basin. However, due to limited data availability, observed values are for the time period 1961-1970 only, while computed values are for 1961-
1990. River flow alterations due to dams and withdrawals are computed to be small, with an annual discharge reduction of 5\%. Reductions are highest in the summer, when irrigation takes place. Computed climate change impacts differ strongly between the two climate models, and only slightly between the two emissions scenarios. According to the ECHAM4 climate model, discharges will strongly decrease from April to October, and increase during winter, due to increased rain and snowmelt. Furthermore, peak flow will be shifted from April to March, and will decrease by approximately $30 \%$. October low flow will decrease by $31 \%$ in the case of emissions scenario A2, and by $17 \%$ in the case of B2. Annual flows will decrease by $18 \%$ (emissions scenario A2) or $8 \%$ (B2). With the HadCM3 climate model, smaller changes of the seasonal hydrograph are predicted. While winter flows will increase similar to the ECHAM4 predictions, peak flows will be shifted and lowered much less, but discharge will be consistently below ANT values from April to October for the time period 1961-1990. Long-term average annual discharge will not change significantly. Consequences of these changes of the Danube river flow regime due to climate change may include disruption of spawning, with decreased reproduction and recruitment, decreased oxygen concentrations in the summer and alteration of floodplain vegetation, decreases in young fish and other effects of decreased duration of floodplain inundation (Scheurer et al., 2009; Poff and Zimmerman, 2010).

WGHM is able to simulate the strongly seasonal discharge of the Volga, even though observed winter flows are somewhat underestimated, while April and May flows (melting season) are slightly overestimated (Fig. 7). According to WGHM, damming of the Volga caused significant seasonal flow homogenization, with increases in winter flows due to higher temperatures, and significant decreases of seasonal high flows caused by melting. Long-term average annual river discharge decreased by $6 \%$ due to damming and water withdrawals. According to ECHAM4, climate change will lead to significant increases in river discharge from November to May. Peak flow will be shifted from May to April, and March and April flows are predicted to more than double by the 2050s. Annual river discharge will increase by more than $35 \%$, and would then be $30 \%$ larger than natural flows under the 1961-1990 climate. Like in the Danube, discharge changes as predicted by using HadCM3 input are smaller, but go in the same direction. Higher winter flows and earlier and higher spring flows can be expected to lead to increased sediment transport, disruption of spawning, decreased reproduction and recruitment, and to a change in assemblage structure (Scheurer et al., 2009; Poff and Zimmerman, 2010). The challenge will be to manage these additional water volumes by reservoir management such that ecosystem well-being is optimized under the new hydrological and temperature conditions. 

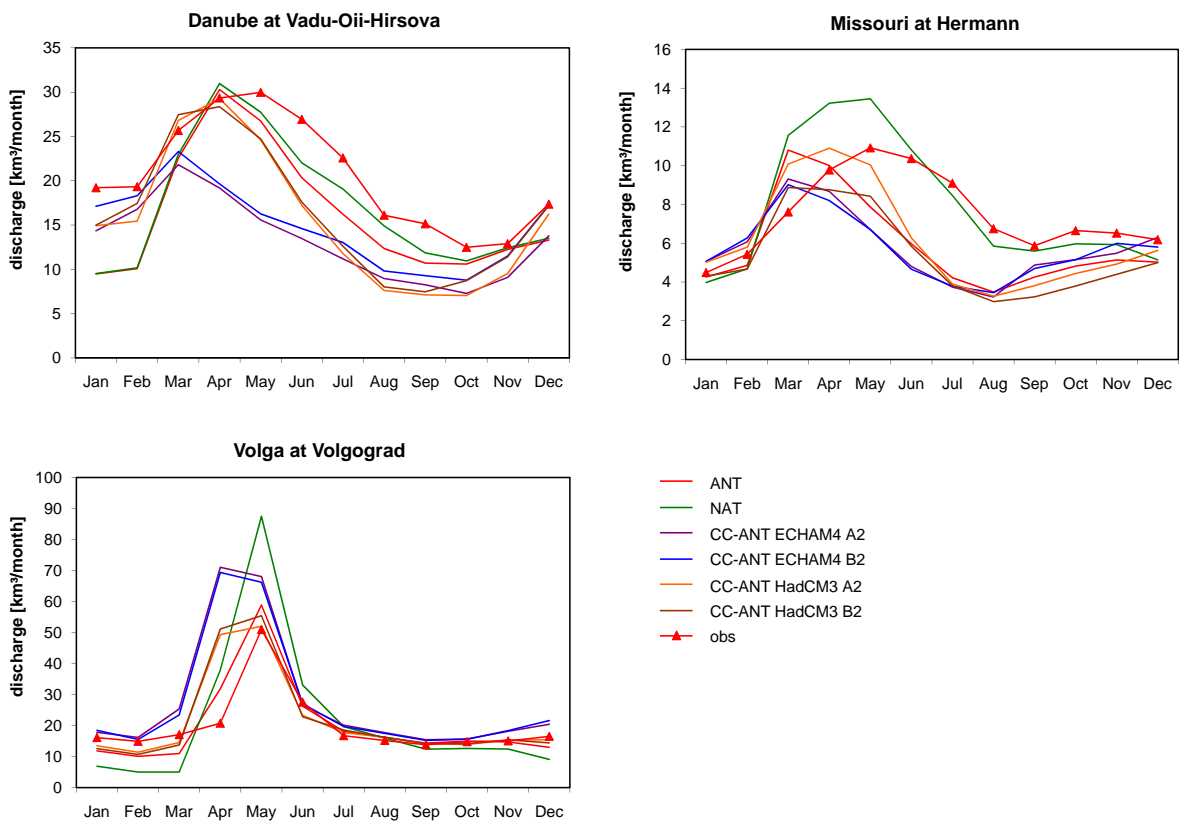

Fig. 7. Long-term average monthly discharge at three observation stations under anthropogenically altered and naturalized conditions for 1961-1990, and under anthropogenically altered conditions for 2041-2070 according to four climate change scenarios. Observation period for Volga is 1961-1990 and for Missouri 1958-1987, but only 1961-1970 for Danube.

For the Missouri at Hermann, a comparison of observed discharges for 1958-1987 to discharges computed by WGHM under the impact of dams and water withdrawals in 2002 is not possible, because withdrawals in 2002 were significantly larger than during the observation period. A computation of discharge during the time period 1980-1999 with temporally changing water withdrawals instead of the constant 2002 water withdrawals used in this study improves somewhat the fit as compared to Fig. 7, but peak flow is still one month too early (Döll et al., 2009, their Fig. 9). In both runs, peak flows are computed with the correct magnitude, but autumn flows are overestimated (Fig. 7). According to WGHM but also to local estimates of naturalized reservoir outflows (Döll et al., 2009, their Fig. 9) dam construction and water withdrawals have caused strong flow decreases between March and December. Regarding the impact of climate change, long-term average annual discharge is approximately stable (less than $10 \%$ increase or decrease) for all four climate scenarios, and there will some slight seasonal shifts, with significantly longer-lasting in summer low flows (Fig. 7). Thus, climate change is likely to further decrease summer low flows, which may lead to further losses of sensitive species (Poff and Zimmerman, 2010).

Regarding changes in species numbers due to climate change as predicted due to changes in long-term average river discharge (Eq. 1), the percent changes in all three rivers are computed to be under 5\% (for the HadCM3 A2 scenario), which is due to only relatively small predicted changes of long-term average river discharge. Considering the considerably larger changes of seasonal flows (Fig. 7), a stronger total impact of future river flow regime alterations on species numbers could be expected. According to Eq. (1), endemic (total) fish species numbers for the Danube, Volga and Missouri are 151 (216), 7 (103) and 76 (105), respectively ("Watersheds of the World: A Special Collection of River Basin Data", http://earthtrends.wri. org/maps_spatial/watersheds/index.php, for Danube, "Freshwater Fishes of Russia", http://www.zin.ru/animalia/pisces/ eng/taxbase_e/fauna_e/volga.htm, for Volga, and "Missouri Fish and Wildlife Information System", http.//mdc4.mdc. mo.gov/applications/mofwis/mofwis_search1.aspx, for Missouri). Compared to the respective species numbers computed for 1961-1990 (including the impact of water withdrawals and reservoirs) of 141, 149 and 132, the computed species number appear to represent more closely total fish species numbers and not endemic fish species numbers for Volga and Missouri but not for Danube.

In our study, the available climate data as well as the method to derive climate scenarios as input to WGHM limited the possibility to evaluate future changes of river flow regimes. For example, the predicted increases in heavy precipitation events could not be represented in our model runs, and changes in interannual climate variability could not be assessed. 


\subsection{Opportunities and further deterioration due to climate change}

Arthington et al. (2010) stated that development of adaptive environmental flow management in response to opportunities and constraints offered by climate-change driven alterations in river flow is a priority. For example, climate change presents opportunities for better managing river flows altered by dams and water withdrawals if it leads to increased river discharge. Figure 8 shows those areas of the globe that have suffered from a decrease of naturalized long-term average discharge by more than $10 \%$ by water withdrawals and dams, and are expected to be subject to either an increase (in green) or a decrease (in yellow) of long-term average discharge of more than $10 \%$ by the 2050s. In the green areas, which are concentrated in Asia and western North America, climate change might provide opportunities to balance past flow regime alterations and reductions of long-term annual discharges as it will increase discharge. There is a chance that those significantly altered drainage areas could be managed in such a way that flow requirement of ecosystems will better taken care of than today. In the yellow areas, however, anthropogenic flow reductions will be strongly exacerbated due to further climate-change induced flow reductions. These areas are located around the Mediterranean Sea, in South Africa, Australia and elsewhere. Depending on the climate model, southern and central India, western China and other areas will either potentially profit or suffer from climate-change induced discharge changes.

Globally, of the $16 \%$ of the land area (outside Greenland and Antarctica) that had suffered from a decrease of naturalized discharge of more than $10 \%$ by $2002,62 \%$ (54\%) might have opportunities for improved flow conditions due to significant increases of annual discharge in the case of the ECHAM4 A2 (HadCM3 A2) climate scenario. On 24\% (29\%) of these heavily stressed areas, climate change will significantly exacerbate the existing flow reductions.

\section{Conclusions}

This study provides a global overview of ecologically relevant river flow alterations due to future climate change until the 2050s. Five indicators of river flow alterations were computed, and their magnitudes and spatial patterns were compared to those of past alterations of the natural flow regimes by dams and water withdrawals by the year 2002 . These indicators describe changes of long-term average annual and monthly river discharges as well as changes of statistical low flows that affect habitat conditions and thus biodiversity of organisms in surface waters and groundwater-dependent vegetation on floodplains. Applying the state-of-the-art global water model WaterGAP, the indicators were quantified with a spatial resolution of $0.5^{\circ}$ by $0.5^{\circ}$.
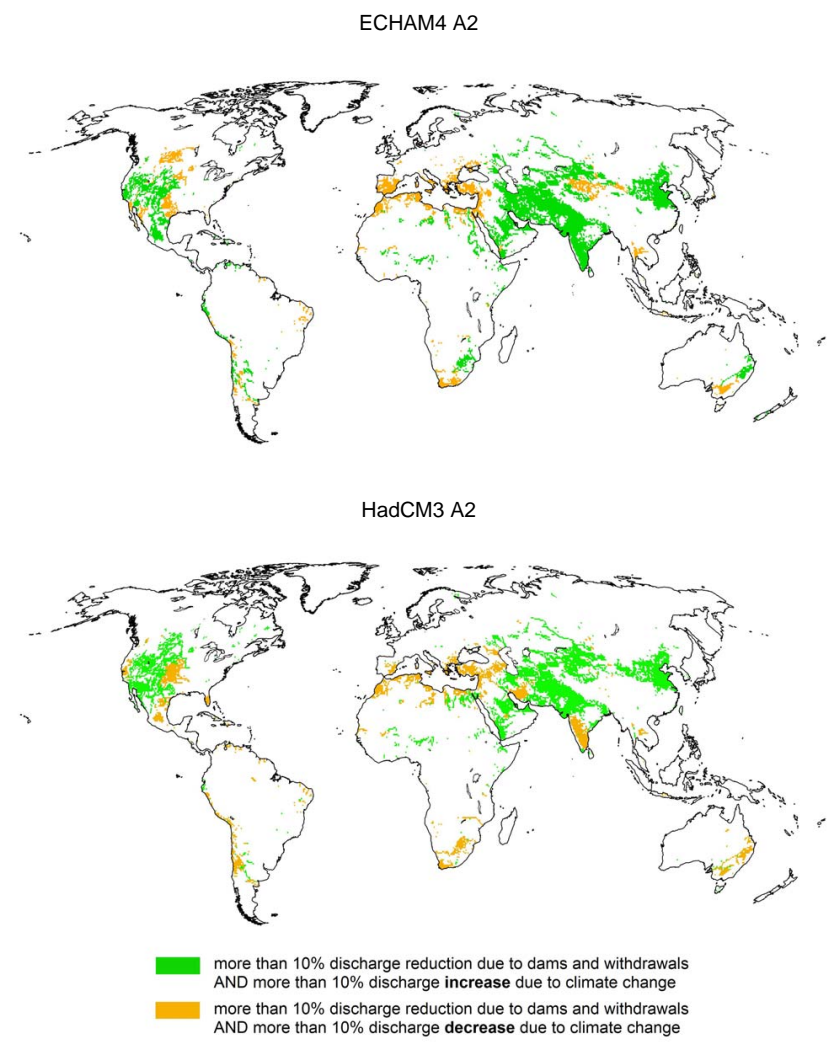

Fig. 8. Areas with significantly reduced long-term average annual discharges due to dams and withdrawals, where discharge increase due to climate change until 2055 may either provide opportunities for ecologically advantageous management of river flows (in green) or where anthropogenic discharge reductions may be significantly exacerbated by climate change (in yellow). Withdrawals and dams in the year 2002, climate change between 1961-1990 and 20412070 according to the emissions scenario A2 as implemented by the global climate models ECHAM4 and HadCM3.

Climate change is likely to have a more widespread and stronger impact on ecologically relevant river flow characteristics than water withdrawals and dam construction have had up to now. However, the reliability of this conclusion is weakened by the fact that the impact of dams is very likely underestimated by our study because small reservoirs have not been taken into account (Döll et al., 2009), impacts of dams shorter than monthly time scales have not been considered, and also the impact of individual dams on monthly flows may be underestimated by our model. According to our computations, the seasonal regime of river flows will have been altered significantly by the 2050s on almost $90 \%$ of the global land area (excluding Greenland and Antarctica) as compared to current conditions ( $\left.I_{\mathrm{SR}} \geq 10 \%\right)$. Up to 2002 , dams and withdrawals had affected only a quarter of the land area by the same degree of alteration of natural flows. The timing of the maximum mean monthly river discharge will be shifted by at least one month on approximately one third 
on the global land area. The maximum often occurs earlier, mainly due to earlier snowmelt. Dams and withdrawals had caused comparable shifts on less than $5 \%$ of the land area.

Only one quarter of the land area will be almost unaffected by changes of long-term average annual river discharges $\left(I_{\mathrm{LTA}}<10 \%\right)$, as compared to five sixth of the land area that has remained almost unaffected by changes due to dams and water withdrawals. On about one half of the global land area, long-term average discharges will increase significantly (i.e. by more than $10 \%$ ) due to climate change. They will decrease by at least that amount on about a quarter of the land area which may lead to significant reductions of endemic fish species in Central and South America, for example. The ecological effects of increased long-term average annual river discharges remain unclear. One reason is that past human interference with river flow regimes, by dams and water withdrawals, has not led to increases but always to decreases of natural long-term average annual river discharge. Therefore, impacts of increased river discharges could not yet have been observed. Correlated with long-term average discharges, the statistical monthly low flows $Q_{90}$ are predicted to increase more often than they are predicted to decrease. However, the area with a significant increase of $Q_{90}$ is smaller than the area with a significant increase of long-term average discharge, while both average discharge and $Q_{90}$ decrease are predicted to significantly decrease on one quarter of the global land area. And it is also one quarter of the land area where water withdrawals had caused significant decreases of $Q_{90}$ by 2002. Four out of the five ecologically relevant river flow characteristics may be affected more strongly by future climate change than by current dams and water withdrawals. The only exception is the decrease of the statistical low flow $Q_{90}$, with significant decreases both by past water withdrawals and future climate change on one quarter of the land area (Please note that the regions with decrease are not the same for the two different stressors).

Knowledge about the impact of flow alterations on freshwater ecosystems suggests that the computed climate induced alterations of river flow regimes will result in strong alterations of freshwater ecosystems regarding species composition in river basins, biodiversity at the ecosystem, species and genetic levels and other aspects. For example, genetic flow and variation of populations of aquatic biota may be reduced due to stream fragmentation that will be caused by decreasing future river discharges (Pringle, 1997).

Poff et al. (2010) presented a new framework (ELOHA: Ecological Limits Of Hydrologic Alteration) for developing regional environmental flow standards. This framework could also be applied to better assess the impact of climate induced flow alterations on freshwater ecosystems. In ELOHA, the first step is quantification of river flow alterations due to human influence, as it was done in this study. In the second step, quantitative relationships between indicators of hydrological alterations and indicators of biotic changes have to be derived. The third step is to classify rivers ac- cording to their natural flow regime such that the quantitative relations, which will only be available for a very restricted number of rivers, can be applied to rivers without ecological data. A number of problems remain. For example, there are probably only few if any data available for ecological responses to increased long-term average discharges or high flows. In addition, ecological responses to climate change depend not only on flow alterations but also on temperature changes and other changes of water quality (e.g. sediment transport). Major research efforts with respect to combined freshwater ecosystem responses to flow and temperature changes are required.

Climate change will exacerbate flow alterations by dams and water withdrawals in some regions, but provide the potential for improvement of the ecological situation in other regions. On the one hand, for $20-30 \%$ of the land area that had suffered from a decrease of naturalized long-term average discharge of more than $10 \%$ by 2002 (16\% of total land area), discharge is expected to decrease by more than an additional $10 \%$ by the $2050 \mathrm{~s}$. Depending on the climate model, the affected regions may include the Mediterranean, parts of North America, the Near East and Western China, the Murray-Darling Basin in Australia and Southern India. On the other hand, on 50-70\%, this decrease may be reduced or even balanced by increased river discharge of more than $10 \%$. In these river basins, climate change presents opportunities for a water management that better takes into account ecosystem water requirements. These regions may include large parts of North America and the Near East, Pakistan and India as well as Northeastern and Northwestern China.

Even river basins without increased water resources could benefit if seasonal river flows become more aligned with seasonal water demands. For example, in case of water demand for hydropower generation in cold regions, where dams are used to increase natural winter discharges, increased winter runoff generation makes seasonal flows more aligned with hydropower demand and may therefore lead to a reduced need of water storage behind dams (Renöfält et al., 2010). In this case, winter flows remain higher as compared to natural flows before climate change, but the negative ecological effects of water storage behind the dam could be reduced.

Acknowledgements. We thank Kristina Fiedler and Martin Hunger for data preparation and execution of model runs. We are grateful to two anonymous reviewers for their thoughtful comments. This study was partly funded by the IPSWaT program of BMBF (German Ministry for Education and Research).

Edited by: B. van den Hurk

\section{References}

Alcamo, J., Döll, P., Henrichs, T., Kaspar, F., Lehner, B., Rösch, T., and Siebert, S.: Development and testing of the WaterGAP 2 global model of water use and availability, Hydrol. Sci. J., 48, 317-337, 2003. 
Arthington, A. H., Naiman, R. J., McClain, M. E., and Nilsson, C.: Preserving the biodeverity and ecological services of rivers: new challenges and research opportunities, Freshwater Biol., 55, 1-16, 2010.

Arthington, A. H. and Pusey, B. J.: In-stream flow management in Australia: methods, deficiencies and future directions, Australian Biol., 6, 52-60, 1993.

Buisson, L., Thuiller, W., Sovan, L., Lim, P., and Grenouillet, G.: Climate change hastens the turnover of stream fish assemblages, Glob. Change Biol., 14, 2232-2248, 2008.

Black, A. R., Rowan, J. S., Duck, R. W., Bragg, O. M., and Clelland, B. E.: DHRAM: a method for classifying river flow regime alterations for the EC Water Framework Directive, Aquat. Conserv., 15, 427-446, 2005.

Döll, P., Fiedler, K., and Zhang, J.: Global-scale analysis of river flow alterations due to water withdrawals and reservoirs, Hydrol. Earth Syst. Sci., 13, 2413-2432, doi:10.5194/hess-13-24132009, 2009.

Döll, P. and Fiedler, K.: Global-scale modeling of groundwater recharge, Hydrol. Earth Syst. Sci., 12, 863-885, doi:10.5194/hess-12-863-2008, 2008.

Döll, P., Kaspar, F., and Lehner, B.: A global hydrological model for deriving water availability indicators: model tuning and validation, J. Hydrol., 270(1-2), 105-134, 2003.

Döll, P. and Siebert, S.: Global modeling of irrigation water requirements, Water Resour. Res., 38(4), 1037, doi:10.1029/2001WR000355, 2002.

Dudgeon, D., Arthington, A. H., Gessner, M. O., Kawabata Z.-I., Knowler, D. J., Lévêque, C., Naiman, R. J., Prieur-Richard, A.H., Soto, D., Stiassny, M. L. J., and Sullivan, C. A.: Freshwater biodiversity: importance, threats, status and conservation challenges, Biol. Rev., 81, 163-182, 2006.

Erwin, K. L.: Wetlands and global climate change: the role of wetland restoration in a changing world, Wetlands Ecol. Manage., 17, 71-84, 2009.

Finlayson, C. M., Gitay, H., Bellio, M. G., van Dam, R. A., and Taylor, I.: Climate variability and change and other pressures on wetlands and waterbirds: impacts and adaptation, Waterbirds Around the World, edited by: Boere, G. C., Galbraith, C. A., and Stroud, D. A., The Stationery Office, Edinburgh, 88-97, 2006.

Fischlin, A., Midgley, G. F., Price, J. T., Leemans, R., Gopal, B., Turley, C., Rounsevell, M. D. A., Dube, O. P., Tarazona, J., and Velichko, A. A.: Ecosystems, their properties, goods, and services. Climate Change 2007: Impacts, Adaptation and Vulnerability. Contribution of Working Group II to the Fourth Assessment Report of the Intergovernmental Panel on Climate Change, edited by: Parry, M. L., Canziani, O. F., Palutikof, J. P., van der Linden, P. J., and Hanson, C. E., Cambridge University Press, Cambridge, 211-272, 2007.

Fuchs, T., Schneider, U., and Rudolf, B.: GPCC Annual Report for Year 2007, GPCC/Deutscher Wetterdienst, online available at: http://gpcc.dwd.de, 2007.

Gibson, C. A., Meyer, J. L., Poff, N. L., Hay, L. E., and Georgakakos, A.: Flow regime alterations under changing climate in two river basins: Implications for freshwater ecosystems, River Res. Applic., 21, 849-864, 2005.

Gordon, C., Cooper, C., Senior, C. A., Banks, H., Gregory, J. M., Johns, T. C., Mitchell, J. F. B., and Wood, R. A.: The simulation of SST, sea ice extents and ocean heat transports in a version of the Hadley Centre coupled model without flux adjustments, Clim. Dynam., 16(2/3) 147-168, 2000.

Hunger, M. and Döll, P.: Value of river discharge data for globalscale hydrological modeling, Hydrol. Earth Syst. Sci., 12, 841861, doi:10.5194/hess-12-841-2008, 2008.

Kundzewicz, Z. W., Mata, L. J., Arnell, N. W., Döll, P., Kabat, P., Jiménez, B., Miller, K. A., Oki, T., Sen, Z., and Shiklomanov, I. A.: Freshwater resources and their management. Climate Change 2007: Impacts, Adaptation and Vulnerability. Contribution of Working Group II to the Fourth Assessment Report of the Intergovernmental Panel on Climate Change, edited by: Parry, M. L., Canziani, O. F., Palutikof, J. P., van der Linden, P. J., and Hanson, C. E., Cambridge University Press, Cambridge, UK, 173-210, 2007.

Lasalle, G. and Rochard, E.: Impact of twenty-first century climate change on diadromous fish spread over Europe, North Africa and the Middle East, Glob. Change Biol., 15, 1072-1089, 2009.

Lehner, B., Reidy Liermann, C., Revenga, C., Fekete, B., Vörösmarty, C., Crouzet, P., Döll, P., Endejan, M., Frenken, K., Magome, J., Nilsson, C., Robertson, J., Rödel, R., Sindorf, N., and Wisser, D.: High resolution mapping of global reservoirs and dams and their downstream river impacts, in preparation, 2010.

Lehner, B., Fekete, B., Reidy, C., and Vörösmarty, C.: Global Reservoir and Dam (GRanD) Database - Project Summary, online available at: http://www.gwsp.org/current_activities.html, 2008.

Lehner, B. and Döll, P.: Development and validation of a global database of lakes, reservoirs and wetlands, J. Hydrol., 296, 1-22, 2004.

Matthews, W. J. and Marsh-Matthews, E.: Effects of drought on fish across axes of space, time and ecological complexity, Freshwater Biol., 48, 1232-1253, 2003.

McGarvey, D. J. and Hughes, R. M.: Longitudinal zonation of Pacific Northwest (USA) fish assemblages and the speciesdischarge relationship, Copeia 2008(2), 311-321, 2008.

Millennium Ecosystem Assessment: Ecosystems and human wellbeing: wetlands and water synthesis. World Resources Institute, Washington, DC, 2005

Mitchell, T. D. and Jones, P. D.: An improved method of constructing a database of monthly climate observations and associated high-resolution grids, Int. J. Climatol., 25, 693-712, 2005.

Nakicenovic, N. and Swart, R. (eds.): Emission Scenarios IPCC Special Report on Emission Scenarios, Cambridge University Press, online available at: http://www.ipcc.ch, 2000.

Poff, N. L. and Zimmerman, J. K. H.: Ecological responses to altered flow regimes: a literature review to inform the science and management of environmental flows, Freshwater Biol., 55, 194 205, 2010

Poff, N. L., Richter, B. D, Arthington, A. H., et al.: The ecological limits of hydrologic alteration (ELOHA): a new framework for developing regional environmental flow standards, Freshwater Biol., 55, 147-170, 2010.

Poff, N. L. and Ward, J. V.: Implications of stream flow variability and predictability for lotic community structure: a regional analysis of stream flow patterns, Can. J. Fish. Aquat. Sci., 46, 1805-1818, 1989.

Pringle, C. M.: Exploring how disturbance is transmitted upstream: going against the flow, J. N. Am. Benthol. Soc., 16, 425-438, 1997. 
Renöfält, B. M., Jansson, R., and Nilsson, C.: Effects of hydropower generation and opportunities for environmental flow management in Swedish riverine ecosystems, Freshwater Biol., 55, 49-67, 2010.

Revenga, C., Campbell, I., Abell, R., de Villiers, P., and Bryer, M.: Prospects for monitoring freshwater ecosystems towards the 2010 targets, Philos. T. Roy. Soc. B, 360, 397-413, 2005.

Richter, B. D., Matthew, R., Harrison, D. L., and Wigington, R.: Ecologically sustainable water management: managing river flows for ecological integrity, Ecol. Appl., 13, 206-224, 2003.

Richter, B. D., Baumgartner, J. V., Powell, J., and Braun, D. P.: A method for assessing hydrologic alteration within ecosystems, Conserv. Biol., 10(4), 1163-1174, 1996.

Röckner, E., Arpe, K., Bengtsson, L., Christoph, M., Claussen, M., Dümenil, L., Esch, M., Giorgetta, M., Schlese, U., and Schulzweida, U.: The atmospheric general circulation model ECHAM-4: Model description and simulation of present day climate, MPI-Report No 218, MPI für Meteorologie, Hamburg, 1996.
Scheurer, K., Alewell, C., Bänninger, D., and Burkhardt-Holm, P.: Climate and land-use changes affecting river sediment and brown trout in alpine countries - a review, Environ. Sci. Pollut. Res., 16, 232-242, 2009.

Siebert, S., Döll, P., Hoogeveen, J., Faures, J.-M., Frenken, K., and Feick, S.: Development and validation of the global map of irrigation areas, Hydrol. Earth Syst. Sci., 9, 535-547, doi:10.5194/hess-9-535-2005, 2005.

Tennant, D. L.: Instream flow regimens for fish, wildlife, recreaton and related environmental resources, in: Instream Flow Needs, edited by: Orsborn, J. F. and Allman, C. H., American Fisheries Society, Bethesda, Maryland, USA, 359-373, 1976.

Xenopoulos, M. A., Lodge, D. M., Alcamo, J., Märker, M., Schulze, K., and van Vuuren, D. P.: Scenarios of freshwater fish extinctions from climate change and water withdrawal, Glob. Change Biol., 11, 1557-1564, 2005. 